\title{
ESKİ KİRACIYA YENIDEN KİRAYA VERME ZORUNLULUĞU
}

\author{
İbrahim GÜL*
}

$\ddot{O} Z$

Konut ve çatılı işyerleri kira sözleşmesinin kiraya veren tarafindan sona erdirilmesi halinde kiraya verenin, eski kiracıslyla yeniden kira sözleşmesi yapmaya zorlandığ söylenebilir. Gerçekten kiraya veren, gereksinim amacıyla kiralananın boşaltılmasını sağladığında, haklı sebep olmaksızın, kiralananı üç yıl geçmedikçe eski kiracısından başkasına kiralayamaz. Bunun gibi esasl onarım amacıyla boşaltılan kiralanan, haklı sebep olmaksızın üç yıl geçmedikçe başkasına eski hâli ile kiralanamaz. Ayrıca eski kiracının, yeniden inşa ve imarı gerçekleştirilen kiralananı yeni durumu ve yeni kira bedeli ile kiralama konusunda öncelik hakkı vardır. Eski kiracının bu öncelikle kiralama hakkı sonlandırılmadıkça, kiralanan üç yıl geçmeden başkasına kiralanamaz. Bütün bu durumlarda kiraya verenin sözleşmenin karşı tarafını seçme özgürlüğüne kısıtlama getirildiği söylenebilir. İ̧̧bu makale ile kiraya verenin eski kiracısına kiraya verme zorunluluğunun şartları açıklanmaktadır.

Anahtar Kelimeler: Kira sözleşmesi, kiralanana gereksinim, yeniden imar ve inşa, yeniden kiralama yasă̆l, tazminat.

\section{THE LANDLORD'S OBLIGATION TO RENT TO THE FORMER TENANT}

\section{ABSTRACT}

In case of termination of lease agreement concerning residence and roofed workplaces by the landlord, he/she can be forced to relet with the former tenant. Indeed, the landlord cannot rent the leased property to other persons than his / her former tenant for three years without a justifiable reason, when the tenant is evicted due to the landlord's need for the property. In the same way, the leased property that is evacuated due to the need for substantial reconstruction or refurbishment, cannot be rented with its pre-reconstruction status to other persons without a justifiable reason unless three years have passed after the date of evacuation. In addition, the former tenant has the priority right to the lease newly reconstructed property with new status and new rent after reconstruction. Unless this priority right is terminated, the leased property cannot be rented to other persons within three years after reconstruction. In all these cases, it can be argued that the landlord's freedom to choose other side

\footnotetext{
Dr. Öğr. Üyesi, Hasan Kalyoncu Üniversitesi Hukuk Fakültesi e-posta: yard.doc.gul@gmail.com

ORCID: 0000-0002-0271-5048

DOI: $10.34246 /$ ahbvuhfd. 637945
}

Yayın Kuruluna Ulaştığı Tarih : 11/07/2019

Yayınlanmasının Uygun Görüldüğü Tarih: 25/09/2019 
of the lease agreements is restricted. This article discusses the requirements of the landlord's obligation to rent the property to the former tenant.

Key Words: Lease contract, need for the property, restoration of the property, priority right of tenant, obligation of landlord to re-rent.

\section{GíRIŞ}

Türk borçlar hukukunda hâkim ilke olarak benimsenen sözleşme özgürlügüune göre kişiler, sözleşmenin karşı tarafını seçmekte özgürdürler ${ }^{1}$. Bununla birlikte sözleşmenin karşı tarafını seçme özgürlüğü bir hukuki işlemle veya bir kanun hükmüyle kısıtlanabilir². Sözleşmenin karşı tarafını seçme özgürlüğüne kanunla getirilen sınırlamalardan bir tanesi, konut ve çatılı işyeri kira sözleşmelerinde bulunmaktadır.

TBK m. 355/I fikra hükmüne göre kiraya verenin veya yeni malikin kiralanana gereksinimi nedeniyle kira sözleşmesini dava yoluyla sona erdirmesi halinde kiralanan, üç yıl geçmedikçe tahliye edilen kiracidan başkasına kiralanamaz. Aynı şekilde TBK m. 355/II fikra hükmüne göre kiralananın yeniden inşası veya imarı amacıyla esaslı onarımı, genişletilmesi ya da değiştirilmesi (esaslı onarım) ${ }^{3}$ için boşaltılması halinde kiralanan, eski hâli ile haklı sebep olmaksızın üç yıl geçmedikçe başkasına kiralanamaz.

1 Sözleşme özgürlüğü hakkında detaylı bilgi için bkz. EREN, (2018), s. 17; OĞUZMAN / ÖZ, s. 23; SEROZAN, s. 50; KILIÇOĞLU (A.), s. 115 vd; AKINCI, (2017), s. 11; ANTALYA, s. 73; BAŞPINAR, s. 13 vd; AYAN (M), s. 10; NOMER, s. 74; HATEMİ / GÖKYAYLA, s. 60 vd; REISOĞLU, s. 133; KOCAYUSUFPAȘAOĞLU (KOCAYUSUFPAȘAOĞLU / HATEMİ / SEROZAN / ARPACI), s. 501; AKINTÜRK/ATEŞ, s. 61; TEKINAY / AKMAN / BURCUOĞLU / ALTOP, s. 363; ZEVKLILLER / ERTAȘ / HAVUTÇU / AYDOĞDU / CUMALIOĞLU, s. 118; AYBAY, s. 38; İNAN / YÜCEL, s. 76, s. 204; BİLGILİ / DEMIRKAPI, s. 44; TERCIER / PICHONNAZ / DEVELIOĞLU, s. 222.

2 Sözleşme özgürlüğünün kısıtlanması hakkında detaylı bilgi için bkz. SEROZAN, s. 50-51; OĞUZMAN/ÖZ, s. 184; EREN, (2018), s. 319; KILIÇOĞLU (A.), s. 116; AKINCI, (2017), s. 14; ANTALYA, s. 73; NOMER, s. 77; AYBAY, s. 42; İNAN/YÜCEL, s. 246; ZEVKLİLER / ERTAŞ / HAVUTÇU / AYDOĞDU / CUMALIOĞLU, s. 121; BAŞPINAR, s. 18; AYAN (M.), s. 10; BILLGILI / DEMIRKAPI, s. 44; TEKINAY / AKMAN / BURCUOĞLU / ALTOP, s. 364; KOCAYUSUFPAŞAOĞLU (KOCAYUSUFPAŞAOĞLU / HATEMİ / SEROZAN / ARPACI), s. 507. Sözleşme yapma zorunluluğu hakkında ayrıntılı bilgi için bkz. GÜRZUMAR, s. 22 vd.

3 Makalede kiralananın yeniden inşası veya imarı amacıyla esaslı onarımı, genişletilmesi ya da değiştirilmesi, esaslı onarım olarak ifade edilecektir. 
Buna ilaveten eski kiracının esaslı onarımı gerçekleştirilen kiralananı yeni durumu ve yeni kira bedeli ile kiralama konusundaki öncelik hakkı, kiraya veren tarafından sona erdirilmedikçe, kiralanan üç yıl geçmeden başkasına kiralanamaz (TBK m.355/II) ${ }^{4}$. Bu üç yıl süreyle kiralananın başkasına kiraya verilememesi, kiraya verenin eski kiracısıyla sözleşme yapma zorunluluğu veya eski kiracısına yeniden kiraya verme zorunluluğu olarak nitelendirilebilir.

Kiraya verenin eski kiracısıyla sözleşme yapma zorunluluğunun söz konusu olabilmesi için kira sözleşmesinin belirli nedenlerle ${ }^{5}$ sona erdirilmesi ve kiracının kiralanandan tahliyeye zorlanması gereklidir ${ }^{6}$. Ayrıca kiraya veren, üç yıl süreyle sınırlı olarak eski kiracıyla sözleşme yapma yükümlülüğü altında olup, eski kiracı dışında başka birine kiraya vermesi haklı bir nedene dayalı ise sözleşme yapma zorunluluğu söz konusu olmaz.

\section{I- KİRA SÖZLEŞMESINIIN SONA ERME NEDENLERİ}

Konut ve çatılı işyerine ilişkin kira sözleşmesi ${ }^{7}$, bildirim veya dava yoluyla sona erdirilebilir ${ }^{8}$. Kira sözleşmesinin bildirim yoluyla sona erdirilmesi, kira sözleşmesinin süresinin belirli veya belirsiz olmasına ${ }^{9}$ göre

4 Yeniden kiralama yasağını düzenleyen TBK m. 355 hükmü nispi emredicidir; bkz. İNCEOĞLU, C.2, s. 534. Aynı doğrultuda bkz. SARUHAN, s. 356.

5 “Örneğin, burada sayılmayan yazılı tahliye taahhüdü nedeniyle taşınmazdan çıkarma, cezanin uygulanması sonucunu doğurmaz.”; bkz. AYDOĞDU / KAHVECİ, s. 666.

6 SARUHAN, s. 355.

7 Konut ve çatılı isyerine ilișkin kira sözleșmesi hakkında bkz. İNCEOĞLU, C. 2, s. 1 vd; GÖKYAYLA, (2018), s. 1955 vd; ACAR, (2017), s. 82 vd; EREN, (2017), s. 393 vd; ARAL / AYRANCI, s. 267 vd; ACAR (YAVUZ / ÖZEN / ACAR), (2016), s. 307 vd; ZEVKLİLER / GÖKYAYLA, s. 196 vd; GÖKYAYLA, (2013), s. 1203 vd; DOĞAN, 6098 Say1lı, s. 507 vd; KOÇAK DİKER, s. 64 vd; AYDEMIR, s. 22 vd; AKINCI, (2008), s. 38 vd; ÖZTÜRK, s. 1553 vd; AYDOĞDU / KAHVECİ, s. 582 vd; GÜMÜŞ, s. 21vd; KILIÇOĞLU (M.), s. 289 vd; ERZURUMLUOĞLU, s. 115 vd; KIRMIZI, s. 306 vd; GÜLER (Z.), s. 713 vd; BURCUOĞLU, (2008), s. 18-46, s. 26 vd; BURCUOĞLU, (1993), s. 10-23; RUHI / RUHİ, s. $26 \mathrm{vd}$.

8 Konut ve çatılı işyerine ilişkin kira sözleşmesinin sona erdirilmesi hakkında detaylı bilgi için bkz. AKGÜN AKAY, s. 13 vd; AYANOĞLU MORALI, s. 2125 vd; EREN, (2017), s. 410 vd; ARAL / AYRANCI, s. 326 vd; ZEVKLILLER / GÖKYAYLA, s. 346 vd; ACAR (YAVUZ / ÖZEN / ACAR), (2016), s. 338 vd; INNCEOĞLU, C. 2, s. 308 vd; GÜMÜŞ, s. 308 vd; DOĞAN, 6098 Sayıll, s. 511 vd; ERZURUMLUOĞLU, s. 121 vd; KOÇAK DİKER, s. 197; AYDEMIR, s. 192 vd; GÜNAY, s. 141 vd; KALENDER, s. 27 vd; KOÇ, s. 27 vd; AYDOĞDU / KAHVECI, s. 641 vd; YAVUZ, s. 657 vd; 165 vd; KILIÇOĞLU (M.), s. 299 vd; KIRMIZI, s. 368 vd; GÜLER (Z.), s. 713 vd; İPEK, s. 59 vd; BURCUOĞLU, (1993), s. 31 vd; ÜNAL, s. 1530 vd; AYSAL, s. 183 vd; ÖZDOĞAN / OYMAK, s. 528 vd.

9 Belirli süreli ve belirsiz süreli kira sözleşmesi hakkında bkz. EREN, (2017), s. 377 vd; KAH- 
farklılık gösterir. Konut ve çatılı işyerine ilişkin belirli süreli kira sözleşmesi, süresinin bitiminden en az on beş gün önce kiracı tarafindan fesih bildiriminde bulunulmadıç̧a, sözleşme süresinin sona ermesi nedeniyle kiraya veren tarafindan sona erdirilemez (Türk Borçlar Kanunu (TBK) m. 347/I) ${ }^{10}$. Ancak kiraya veren, on y1llı uzama süresi sonunda bu süreyi izleyen her uzama yılının bitiminden en az üç ay önce bildirimde bulunmak koşuluyla, herhangi bir sebep göstermeksizin belirli süreli kira sözleşmesine son verebilir (TBK m. 347/I). Belirsiz süreli kira sözleşmelerinde ise kiracı her zaman, kiraya veren ise kiranın başlangıcından on yıl geçtikten sonra, genel hükümlere göre fesih bildirimiyle sözleşmeyi sona erdirebilir (TBK m. 347/II) ${ }^{11}$.

Konut ve çatılı işyeri bakımından kira sözleşmesinin dava yoluyla sona erdirilmesi ise kiracidan ve kiraya verenden kaynaklanan sebepler olarak ikiye ayrıl1r ${ }^{12}$. Kiracıdan kaynaklanan sebepler tahliye taahhüdü, iki haklı ihtar ve kiracının veya birlikte yaşadığı eşinin aynı ilçe veya belde belediye sınırları içinde oturmaya elverişli bir konutunun bulunması (TBK m. 352) ${ }^{13}$;

RAMAN, M. 300, s. 1606 vd; ARAL / AYRANCI, s. 264 vd; ZEVKLILLER / GÖKYAYLA, s. 193 vd; ACAR (YAVUZ / ÖZEN / ACAR), (2016), s. 229 vd; ACAR, (2017), s. 78 vd; AKINTÜRK/ATEŞ, s. 270; İNCEOĞLU, C. 1, s. 36 vd; KURŞAT, s. 4 vd; AYDOĞDU / KAHVECİ, s. 390 vd; KILIÇOĞLU (M.), s. 57 vd; DOĞAN, 6098 Sayılı, s. 502; AYDIN, s. $45 \mathrm{vd}$.

10 Detaylı bilgi için bkz. AYANOĞLU MORALI, s. 2125 vd; İNCEOĞLU, C. 2, s. 308 vd; AKGÜN AKAY, s. 15 vd.

11 Ayrıca bkz. KÖSTEKÇİ, s. 1 vd; BİRİNCİ UZUN, s. 137 vd; SANLI, s. 105 vd.

12 "Kira sözleşmesinin dava yoluyla sona erdirilme sebepleri sinırlıdır. Dolayısıyla, TBK. m. 354 'e göre, dava yoluyla kira sözleşmesinin sona erdirilmesine ilişkin hükümler, kiracı aleyhine değiştirilemez, yeni dava sebepleri geliştirilemez. Ancak, genel hükümlerde yer alan olağanüstü fesih sebeplerinin gerçekleşmesi hâlinde konut ve çatılı işyerlerine iliş̧kin kira sözleşmeleri de sona erdirilebilir.” EREN, (2017), s. 413. Aynı yönde bkz. İNCEOĞLU, C. 2, s. 182 vd; ARAL / AYRANCI, s. 328; ZEVKLILER / GÖKYAYLA, s. 338; ACAR (YAVUZ / ÖZEN / ACAR), (2016), s. 344. Ayrıca bkz. AKGÜN AKAY, s. 37 vd; ÖZTÜRK, s. 1560 vd; AYANOĞLU MORALI, s. 2125 vd; GÜNAY, s. 253 vd; YAVUZ, s. 861 vd. Yargitay'a göre de “Kiralanan çatılı işyeri vasfinda olduğundan 6098 sayılı TBK'nın Konut ve Çatılı İsyeri Kiraları hükümlerine tabi olup, kanunda belirtilen tahliye sebepleri sinırl-dır. Aynı Yasanın 354. maddesine göre dava yoluyla kira sözleşmesinin sona erdirilmesine ilişkin hükümler kiracı aleyhine değiştirilemez, 347. maddesi gereğince kiracı kira süresinin bitiminden en az on beş gün önce kiralananı tahliye edeceğini kiralayana yazı ile bildirmek suretiyle sözleşmeyi feshetmedi takdirde, sözleşme aynı şartlarla bir yıl daha uzamış sayılır. TBK' 'n Konut ve Çatılı Issyerleri hakkındaki hükümler kiralayana sözleşme maddesine dayanarak feshi ihbar nedeniyle akdi fesih hakkı tanımaz. Türk Borçlar Kanunu'nda ve özel kanunlarda gösterilen haller dişındaki sebeplerle tahliye kararı verilemez."; bkz. Y. 6.HD 25.6.2015 T. 2015/4496 E. 2015/6451 K. -Kazancı İçtihat Programı (erişim: 31.12.2018).

13 Bu sebepler hakkında ayrıntılı bilgi için bkz. İNCEOĞLU, C. 2, s. 423 vd; AYDOĞDU / KAHVECI, s. 677 vd; AYDEMİR, s. 221 vd; AKGÜN AKAY, s. 132 vd; YAVUZ, s. 790 
kiraya verenden kaynaklanan sebepler ise kiraya verenin veya yeni malikin kiralanana gereksinimi ve kiralananın yeniden inşa ve imar amacıyla esaslı onarıma ihtiyacının olmasıdır (TBK m. 350, m. 351) ${ }^{14}$.

$\mathrm{Bu}$ çerçevede eski kiracıya kiraya verme zorunluluğunun söz konusu olabilmesi için kiraya verenden kaynaklanan sebeplerle kira sözleşmesinin sona erdirilmesi hallerinden olan kiraya verenin veya yeni malikin kiralanana gereksinimi veya kiralananın yeniden inşa ve imar amacıyla esaslı onarıma ihtiyacının olması nedeniyle kira sözleşmesinin sona erdirilmesi ve kiralananın boşaltılmasının sağlanması gereklidir.

\section{II- KİRAYA VERME ZORUNLULUĞUNA NEDEN OLAN KİRA SÖZLEŞMESİ SONA ERME NEDENLERİ}

Kiracıya yeniden kiraya verme zorunluluğu, konut ve çatılı işyeri kira sözleşmesinin üç nedenle sona erdirilmesi halinde söz konusu olur ${ }^{15}$. Bunlar; konut ve çatılı işyeri kira sözleşmesinin kiraya verenin kiralanana gereksinimi nedeniyle sona erdirilmesi, yeni malikin kiralanana olan gereksinimi nedeniyle sona erdirilmesi ${ }^{16}$ ve kiralananın esaslı onarımı nedeniyle kira

vd; ÖZTÜRK, s. 1578 vd; EREN, (2017), s. 422 vd; ARAL / AYRANCI, s. 333 vd; ACAR (YAVUZ / ÖZEN / ACAR), (2016), s. 355 vd; ZEVKLILER / GÖKYAYLA, s. 363 vd; GÜMÜŞ, s. 325 vd; DOĞAN, 6098 Sayıl1, s. 514 vd; KILIÇOĞLU (M.), s. 354 vd; KIRMIZI, s. 501 vd; KALENDER, s. 33 vd; İPEK, s. 76 vd; ÖZDOĞAN / OYMAK, s. 559 vd; BURCUOĞLU, (2008), s. 39 vd; BURCUOĞLU, (1993), s. 175 vd. Yargitay kararları için bkz. GÜNAY, s. 233 vd; YAVUZ, s. 790 vd; TUNABOYLU, s. 918 vd, s. 991 vd, s. 1089 vd; CERAN, s. 883 vd, s. 916 vd, s. 951 vd.

14 Kiraya verenden kaynaklanan tahliye sebepleri hakkında ayrıntılı bilgi için bkz. AKGÜN AKAY, s. 37 vd; İNCEOĞLU, C. 2, s. 340 vd; AYDOĞDU / KAHVECI, s. 654 vd; AYDEMIR, s. 194 vd; YAVUZ, s. 689 vd. ÖZTÜRK, s. 1561 vd; EREN, (2017), s. 413 vd; ARAL/ AYRANCI, s. 329 vd; ACAR (YAVUZ / ÖZEN / ACAR), (2016), s. 348 vd; ZEVKLİLER / GÖKYAYLA, s. 346 vd; GÜMÜŞ, s. 341 vd; DOĞAN, 6098 Sayıl1, s. 513 vd; KILIÇOĞLU (M.), s. 319 vd; KIRMIZI, s. 387 vd; ÖZDOĞAN / OYMAK, s. 536 vd; KALENDER, s. 34; BURCUOĞLU, (2008), s. 36 vd; BURCUOĞLU, (1993), s. 355 vd. Yargitay kararları için bkz. GÜNAY, s. 233 vd; YAVUZ, s. 689 vd; TUNABOYLU, s. 600 vd, s. 692 vd, s. 826 vd, s. 874 vd; CERAN, s. 758 vd, s. 783 vd, s. 838 vd; s. 857 vd

15 SARUHAN, s. 356.

16 Kiraya verenin kiralananı kendisi, eşi, altsoyu, üstsoyu veya kanun gereği bakmakla yükümlü olduğu diğer kişiler için konut ya da işyeri gereksinimi sebebiyle kullanma zorunluluğu varsa belirli süreli sözleşmelerde sürenin sonunda, belirsiz süreli sözleşmelerde kiraya ilişkin genel hükümlere göre fesih dönemine ve fesih bildirimi için öngörülen sürelere uyularak belirlenecek tarihten başlayarak bir ay içinde açacağ 1 dava ile konut ve çatılı işyeri kira sözleşmesini sona erdirebilir (TBK m. 350/f.1 b.1). Kiraya verenin gereksin nedeniyle tahliye davası açması için önceden ihtarda bulunmasına gerek yoktur. Yeni malik (kiralananı sonradan edinen kişi) ise kiralananı kendisi, eşi, altsoyu, üstsoyu veya kanun gereği 


\section{sözleşmesinin sona erdirilmesidir ${ }^{17}$. Kiralananın esaslı onarım nedeniyle}

bakmakla yükümlü olduğu diğer kişiler için konut veya işyeri gereksinimi sebebiyle kullanma zorunluluğu varsa, edinme tarihinden başlayarak bir ay içinde durumu kiracıya yazılı olarak bildirmek koşuluyla, konut ve çatılı işyeri kira sözleşmesini altı ay sonra açacağ bir davayla sona erdirebilir (TBK m. 351/I). Bunun dişında yeni malik, kira sözleşmesine halef olması dolayısıyla kazanacağı kiraya veren sıfatıyla da kira sözleşmesini, TBK m. 350 hükmüne uygun olarak sona erdirebilir (TBK m. 351/II, m. 350, m. 310/I). Gereksinim nedenine dayalı olarak konut ve çatılı işyeri kira sözleşmesinin sona erdirilmesi hakkında ayrıntılı bilgi için bkz. İNCEOĞLU, C. 2, s. 340 vd; AKGÜN AKAY, s. 37 vd; AYDOĞDU / KAHVECİ, s. 654 vd; EREN, (2017), s. 414 vd; ARAL / AYRANCI, s. 329 vd; ZEVKLILER / GÖKYAYLA, s. 346 vd; ACAR (YAVUZ / ÖZEN / ACAR), (2016), s. 348 vd; GÜMÜŞ, s. 341 vd, s. 357 vd; AYDEMIR, s. 194 vd; ÖZTÜRK, s. 1561 vd; YAVUZ, s. 689 vd; BURCUOĞLU, (1993), s. 355 vd; TOSUN, s. 31 vd; SSENER, s. 3 vd; BATUR, s. 216-220, s. 216 vd; AYAN (N.), s. 11 vd. Yargıtay'a göre “Türk Borçlar Kanunu'nun 350/1 ve 351. maddelerine göre işyeri ihtiyacına dayalı olarak açılan tahliye davalarında ihtiyaçlının kirada olması halinde ihtiyacın varlığının kabulü için ihtiyaçlının ya tahliye tehdidi altında bulunması veya kiralananın yapılacak iş için daha üstün nitelikte olması, en azından halen iş yapılan yerle eşdeğer nitelikte bulunması gerekir. Eşdeğerlik durumu varsa mülkiyet hakkına üstünlük tanınmalıdır. Bu iki halden birisinin varlığl ihtiyacın kabulü için yeterlidir. Her iki halin birlikte olması gerekmez. Tahliye tehdidinin varlığl davacı tarafindan ileri sürülmemiş ise mahkemece kendiliğinden nazara alınmaz. Oysa kiralananın halen iş yapılan yerde üstün olduğu ileri sürülmemiş olsa bile ihtiyaç iddiasının içinde bu husus da mevcut olduğundan mahkemece uzman bilirkişi aracıliğtyla keşif yapılarak kiyaslama suretiyle bu hususun belirlenmesi gerekir." Y. 3. HD 23.01.2018 T. 2017/8534 E. 2018/509 K.; bkz. Yargıtay Kararları Dergisi (YKD), 2018/3, s. 557. Diğer Yargıtay kararları için bkz. Y. 1. HD 11.12.1997 T. 1997/16143 E. 1997/16675 K. bkz. YKD., 1998/6, s. 844; Y. 6. HD 15.12.1997 T. 1997/10385 1997/10569 K. bkz. YKD., 1998/2, s. 207; Y. 6. HD 18.10.1989 T. 1989/13230 E. 1989/15630 K. bkz. YKD., 1990/2, s. 211; YHGK 10.2.1960 T. 1960/6-2 E. 1960/5 K. bkz. AD. 1960/3-4, s. 92; Y. 3. HD 6.12.2017 T. 2017/7019 E. 2017/17123 K.; Y. 3. HD 22.2.2018 T. 2017/8924 E. 2018/1578 K.; Y. 6.HD 30.5.2016 T. 2015/11227 E. 2016/4220 K. -Kazancı İçtihat Programı (erişim: 31.12.2018). Ayrıca bkz. GÜNAY, s. 194 vd, s. 214 vd; ERDOĞAN, s. 815 vd; s. 874 vd, s. 1002 vd.

17 Kiraya veren kira sözleşmesini, kiralananın yeniden inşası veya imarı amacıyla esaslı onarımı, genişletilmesi ya da değiştirilmesi gerekli ve bu işler sırasında kiralananın kullanımı imkânsız ise belirli süreli sözleşmelerde sürenin sonunda, belirsiz süreli sözleşmelerde kiraya ilişkin genel hükümlere göre fesih dönemine ve fesih bildirimi için öngörülen sürelere uyularak belirlenecek tarihten başlayarak bir ay içinde açacağı dava ile sona erdirebilir. (TBK m. 350/f.1 b.2). Kiraya verenin tahliye davası açması için önceden ihtarda bulunmasına gerek yoktur. Kiraya verenin esaslı onarım nedeniyle kira sözleşmesinin sona erdirmesi, kiralananın ayıplı olması nedeniyle geçici boşaltmadan (TBK m. 320) farklıdır. Bu nedenle kiralananın, ayıplı olması nedeniyle geçici boşaltmasında yeniden kiralama yasağı söz konusu olmaz. Esaslı onarım nedeniyle kira sözleşmesinin sona erdirilmesi hakkında ayrıntılı bilgi için bkz. İNCEOĞLU, C. 2, s. 504 vd; AKGÜN AKAY, s. 94 vd; AYDOĞDU / KAHVECİ, s. 666, s. 671 vd; EREN, (2017), s. 420 vd; ARAL / AYRANCI, s. 332 vd; ZEVKLILER / GÖKYAYLA, s. 361 vd; GÜMÜŞ, s. 353 vd; ACAR (YAVUZ / ÖZEN / ACAR), (2016), s. 353 vd; AYDEMIR, s. 209 vd; ÖZTÜRK, s. 1571 vd; YAVUZ, s. 689 vd; BURCUOĞLU, (1993), s. 453 vd. Y. 6. HD 21.5.1981 T. 1981/3386 E. 1981/8575 K. bkz. YKD., 1981/11, s. 1428-1429; Y. 6. HD 6.6.1980 T. 1980/1864 E. 1980/5911 K. bkz. YKD., 1981/3, s. 298. 
kira sözleşmesinin sona erdirilmesinde kiracıya kiraya verme zorunluluğu iki halde söz konusudur. Bunlardan birincisi kiracının kiralanandan tahliye edilmesi sonrasında kiralananın esaslı onarımının yapılmaması üzerine esaslı onarım yapılmayan kiralananın eski hali ile üç yıl süreyle eski kiracı dışında başkasına kiraya verilememesidir (TBK m.355/II). İkinci hal ise kiralananın esaslı onarım sonrasında, eski kiracının öncelik hakkı sona erdirilmedikçe, üç yıl boyunca eski kiracı dışında başkasına kiralanamamasıdır (TBK m.355/ II $)^{18}$. Eski kiracıya kiralama zorunluluğuna sebep olan bu nedenlerin temel özelliği, kira sözleşmesinin kiraya verenden kaynaklanan nedenlerle sona erdirilmesidir.

Eski kiracıya kiraya verme zorunluluğunun geçerli olabilmesi için yukarıda belirtilen kira sözleşmesinin sona erdirilmesinde Yasa'nın aradı̆̆1 şartların bulunması gereklidir. Bu sona erme nedenlerinin şartlarını bu makale ile açıklamak makalenin kapsamını aşacağından ve eski kiracıya kiraya verme zorunluluğu bakımından önemli olanın kira sözleşmesinin yukarda açıklanan nedenlerle sona ermesi olduğundan burada kira sözleşmesinin sona ermesi için aranan şartlar açıklanmayacaktır. Bununla birlikte eski kiracıya kiraya verme zorunluluğu bakımından önem arz eden bazı hususların açıklığa kavuşturulmasında fayda vardır.

Bunların başında kiralanana gereksinim nedeniyle kira sözleşmesinin sona erdirilmesinde kiraya veren sifatının $^{19}$ yorumlanması gelmektedir. Gerçekten kiralanana gereksinim nedeniyle kira akdinin sona erdirilmesi nedeniyle eski kiracıya kiraya verme zorunluluğu getiren TBK m. 355 hükmü, kiraya veren terimine yer vermektedir. Bu bakımından kiraya veren sıfatının, kiralananı sonradan edinen maliki kapsayıp kapmadığının belirlenmesi önem

18 Kiraya veren kiracıyı kiralanandan tahliye ettikten ve yapım ve onarım tamamlandıktan sonra kiraya verenin, kiralananı yeni durumuyla ve buna uygun yeni fiyatıyla eskiden kiralananı kullanan kiracıya kiralama hakkının olduğunu yazılı olarak bildirmesi gereklidir. Kiracı, aldığ 1 bu bildirime bir ay içinde olumlu cevap vermez ise kiralananı öncelikle kiralama hakkını yitirir. Kiracı kiraya verenin teklifini kabul ederse, yeni bir kira sözleşmesi kurulur. Kiracının kiralananı öncelikle kiralama hakkına ilişsin detaylı bilgi için bkz. AYDOĞDU / KAHVECİ, s. 676 vd; İNCEOĞLU, C. 2, s. 537 vd; AKGÜN AKAY, s. 113 vd; EREN, (2017), s. 422; ARAL / AYRANCI, s. 328; ZEVKLİLER / GÖKYAYLA, s. 362; ACAR (YAVUZ / ÖZEN / ACAR), (2016), s. 347; AYDEMIR, s. 213; DOĞAN, Konut ve Çatıl1, s. $145 \mathrm{vd}$; AKYİĞİT, s. 216. SARUHAN'a göre kiracıya öncelik hakkını kullanması için tanınan bir aylık süre, hak düşürücü süre mahiyetindedir; bkz. SARUHAN, s. 370.

19 Kiraya verenin malik olmasına gerek yoktur. Kiraya veren sıfatı hakkında bkz. İNCEOĞLU, C. 1, s. 50 vd; KAHRAMAN, M. 299, s. 1599 vd; ACAR, (2017), s. 63 vd; AYDEMIR, s. 39; AKGÜN AKAY, s. 73 vd; AYDOĞDU / KAHVECİ, s. 369 vd; ZEVKLİLER / GÖKYAYLA, s. 184 vd; AKYİĞíT, s. 70. 
arz etmektedir. Kiralananı sonradan edinen malikin, eski kiraya verenle kiracı arasındaki kira sözleşmesine halef olarak kira sözleşmesini gereksinim nedeniyle sona erdirmesi halinde (TBK m. 351/II, m. 350/I, b.1, m. 310/I), kiraya verene halef olarak kiraya veren sıfatı kazandığından ${ }^{20}$ yeni malik için de eski kiracıya kiraya verme zorunluluğunun geçerli olduğu kabul edilmelidir.

Diğer yandan kiralananı sonradan edinen malikin kira sözleşmesine halef olarak değil, kiralananı sonradan edinen malik olarak gereksinim nedeniyle kira sözleşmesini sona erdirmesi halinde, yeni malikin kiraya veren sıfatının olmadığ 1 gerekçesiyle hakkında eski kiracıya kiraya verme zorunluluğunun söz konusu olmadığı söylenebilir. Ancak eski kiracıya kiraya verme zorunluluğu kiraya verenin kiralanana olan gereksiniminin göstermelik olmasını önlemeyi amaçladığ1 ve kiralananı sonradan edinen malikin, kira sözleşmesini sona erdirmesinin gereksinim nedenine dayalı olduğu düşünüldüğünde, kiralananı sonradan edinen malik için de eski kiracıya kiraya verme zorunluluğunun geçerli olduğu kabul edilmelidir ${ }^{21}$.

Bunların yanında Yasa hükmünde yer almamakla birlikte kiraya veren dışında malik veya intifa hakkı sahibinin kiralanana olan gereksinimi nedeniyle kira sözleşmesinin sona erdirilebileceği kabul edilebilir ${ }^{22}$. Bu durumda kiraya

20 TBK m. 310/I hükmüne göre kiralanan sözleşmenin kurulmasından sonra herhangi bir sebeple el değiştirirse, yeni malik kira sözleşmesinin tarafı olur. Ayrıntılı bilgi için bkz. ÖKTEM ÇEVIK, s. 1699 vd; İNCEOĞLU, C. 1, s. 573 vd; ACAR, (2017), s. 236 vd; AYDEMIR, s. 49; AKGÜN AKAY, s. 131; AYDOĞDU / KAHVECİ, s. 669; EREN, (2017), s. 440; ZEVKLİLER / GÖKYAYLA, s. 272; AKYİĞİT, s. 96, s. 210, s. 219. Ayrıca bkz. İKİZLER, s. 25 vd. Yargitay kararı için bkz. Y. 3. HD, 27.3.1984 T. 1984/780 E. 1984/1501 K. bkz. YKD., 1984/7, s. 1021.

21 Aynı yönde bkz. EREN, (2017), s. 420.

22 Boşaltma davasını kiraya veren dışında kiraya veren olmayan malik ya da intifa hakkı sahibinin de açabileceği konusunda Yasa hükmünde bir açıklık bulunmamakla birlikte Yargıtay tarafindan kabul edilmektedir. Bkz. Y. 6. HD 28.2.1980 T. 1980/10258 E. 1980/1793 K.; bkz. YKD., 1980/10, s. 1355 vd; Y. 6. HD 3.3.1988 T. 1988/2035 E. 1988/3027 K. bkz. YKD., 1988/11, s. 1511 vd; YHGK 13.12.1989 T. 1989/6-584 E. 1989/K. 652; bkz. UYGUR, s. 6414; Y. 6. HD 29.04.2008 T. 2008/3082 E. 2008/5514 K.; bkz. RUHI, C. 1, s. 910; Y. 6. HD 28.01.2010 T. 2009/10893 E. 2010/660 K.; bkz. RUHI, C. 1, s. 974. Y. 6. HD 30.11.2006 T. 2006/9443 E. 2006/12237 K.- Kazancı İçtihat Programı (erişim: 31.12.2018); YHGK 22.12.2010 T. 2010/6-659 E. 2010/682 K.; karar için bkz. ZEVKLİLER / GÖKYAYLA, s. 348, dipnot 498. "Tahliye davası açabilmek için "kiraya veren" sıfatına sahip olmak gerekmektedir (6570 sayılı K. mad. 7/I; esasen Borçlar Kanunu'nun sistemi de fesih açısından farklı değildir). Şu hâlde, söz konusu sıfat bir başkasına aitse, malikin ihtiyacı tahliye sebebi olmayacaktır. Mesela, kira konusu yer intifa hakk sahibi tarafindan kiraya verilmişse, kuru mülkiyet sahibinin, yani malikin ihtiyacı tahliye sebebi olamaz."; ARPACI (HATEMİ / SEROZAN / ARPACI), s. 215. Aynı yönde bkz. ZEVKLILER / GÖKYAYLA, s. 347. Aynı yöndeki karar için bkz. Y. 6. HD 2005/3237 E. 2005/4915 K.-Kazancı İçtihat Programı (erişim: 31.12.2018). Öğretide görüşler ve tartışmalar için bkz. İNCEOĞLU, C. 2 , 
veren dışında kira sözleşmesini sona erdiren için de eski kiracıya kiraya verme zorunluluğu söz konusu olabilir ${ }^{23}$. Ayrıca kiralananın tahliye nedenine aykırı olarak kiraya verilmesi durumunda da eski kiracıya kiraya verme zorunluluğu gündeme gelebilir.

Yeni malik sıfatının miras, cebrî icra, mahkeme ilamı gibi bir sebeple sicil dışı kazanılması, eski kiracıya kiraya verme zorunluluğu bakımından bir fark yaratmaz. Önemli olan gerek sicil dışı gerekse sicil yoluyla malik sıfatının kazanılması sonrasında kiracıya yazılı bildirimin usule uygun yapılmasıdır ${ }^{24}$. Aksi taktirde kira sözleşmesinin gereksinim nedeniyle sona ermesi için aranan şartlar oluşmayacağından, eski kiracıya kiraya verme zorunluluğu söz konusu olmayabilecektir.

Diğer yandan kiralananın esaslı onarımı sonrasında eski kiracının kiralananı yeni durumu ve yeni kira bedeli ile kiralama konusundaki öncelik hakk1 ${ }^{25}$, kiraya verenin kiralananı başkasına kiraya vereceği hallerde söz konusu olacağından, kiraya verenin kendisinin kullanacak olması veya kiralananı satması halinde eski kiracıya kiraya verme zorunluluğu söz konusu olmayacaktır ${ }^{26}$.

s. 367 vd; AKYİĞİT, s. 175; DOĞAN, 6098 Say1lı, s. 75; AKGÜN AKAY, s. 74 vd.

23 Aynı doğrultuda bkz. AKYİĞİT, s. 210.

24 Bildirimin usulüne uygun olması için, mülkiyeti kazanım tarihinden itibaren bir aylık sürede yazılı olarak yapılması gereklidir. Ayrıca bkz. ACAR (YAVUZ / ÖZEN / ACAR), (2016), s. 352; İNCEOĞLU, C. 2, s. 392 vd; AYDEMIR, s. 215; AKGÜN AKAY, s. 126; AYDOĞDU / KAHVECİ, s. 669; EREN, (2017), s. 419; ZEVKLİLER / GÖKYAYLA, s. 358; AKYİĞİT, s. 210 , s. 229

25 Gereksinim nedenine dayalı olarak kira sözleşmesinin sona erdirilmesi halinde öncelik hakkının verilmemesinin isabetli olduğu hakkında bkz. İNCEOĞLU, C. 2, s. 403, s. 536; AKGÜN AKAY, s. 92-93. 6570 sayılı Yasa döneminde aynı doğrultudaki görüş bkz. BURCUOĞLU, (1993), s. 474-475. Aksi görüş için bkz. AYDOĞDU / KAHVECİ, s. 664. Akyiğit'e göre gereksinim nedenli boşaltımlarda da hiç değilse eski kira bedeliyle kiralama önceliğinin eski kiracıya tanınması ve yazılı bildirim üzerine kiracının bir aylık sürede vereceği cevaba göre durumun netleşeceği öngörülebilirdi. Örneğin üç y1llık süre dolmadan eski kiracının ölmesi halinde, artık bu süreyi beklemeye gerek olmadığı, kiracının hiç veya kiralanana ihtiyaç duyan mirasçısının ortağının kalmaması gibi; bkz. AKYİĞìT, s. 212.

26 DOĞAN, 6098 Sayıl1, s. 146; İNCEOĞLU, C. 2, s. 420, s. 438; ÖZDOĞAN / OYMAK, s. 580; AKGÜN AKAY, s. 114; BURCUOĞLU, (1993), s. 472; EKİNCİ, s. 91. Ayrıca bkz. Y. 6. HD 05.11.1959 T. 1959/8280 E. 1959/6680 K.; karar için bkz. BURCUOĞLU, (1993), s. 472. Malikin kiralananı kendisinin kullanması halinde dahi kiracıya öncelik hakkını kullandırması gerektiği hakkında Yargıtay kararı için bkz. Y. 4 HD 19.4.2007 T. 2006/7151 E. ve 2007/5305 K.-Kazanc1 İçtihat Programı (erişim: 31.12.2018). 


\section{III- KİRACININ TAHLIYYYE ZORLANMASI}

Eski kiraciya kiraya verme zorunluluğunun söz konusu olabilmesi için aranan diğer şart, kiracının kiralananı tahliyeye zorlanmasıdır ${ }^{27}$. Her ne kadar eski kiracıya kiraya verme zorunluluğuna yol açan kira sözleşmesinin sona erme nedenleri kiraya veren tarafindan dava yoluyla sona erdirilmesi olsa da eski kiracıya kiraya verme zorunluluğunun geçerli olabilmesi için kiraya veren tarafından her halükârda dava edilerek kiracının tahliyesinin sağlanması aranmamalıd $1 r^{28}$. Bu noktada kira sözleşmesini dava yoluyla sona erdirme şartının kiracıyı korumak amacına hizmet ettiği gözetilmelidir. Bu şartın aranması kiracı yerine kiraya verenin korunması sonucuna yol açacağından, eski kiracıya kiraya verme zorunluluğunun kiracıyı koruma amacıyla kabul edilmesi düşüncesi ile de bağdaşmaz. Burada önem arz eden husus, eski kiraciya kiraya verme zorunluluğuna yol açan kira sözleşmesi sona erme nedenine dayalı olarak kiraya verenin talebiyle kiralananın boşaltılmasıdır ${ }^{29}$. $\mathrm{Bu}$ nedenle tarafların anlaşmaları veya ihtar üzerine kiralananın boşaltılması halinde de eski kiracıya kiraya verme zorunluluğunun bulunduğu kabul edilmelidir ${ }^{30}$. Kiracının kiraya verenin bir talebi olmaksızın kendiliğinden kiralananı boşaltması halinde eski kiracıya kiraya verme zorunluluğu söz konusu olmaz.

\section{IV- KİRAYA VERME ZORUNLULUĞUNUN SÜRESI}

TBK m. 355/I ve II fikrasında eski kiraciya kiraya verme zorunluluğunun süresi, üç yıl olarak düzenlenmiştir. Ancak bu sürenin başlangıcına ilişkin maddede bir hüküm bulunmamaktadır.

Eski kiracıya kiraya verme zorunluluğunun başlangıç tarihi, eski kiraciya kiraya verme zorunluluğuna neden olan kira sözleşmesinin sona erdirilmesi nedenleri gözetilerek ayrı ayrı değerlendirilmelidir. Gereksinim nedenine dayalı veya esaslı onarım sonrasında kiralananın eski hali ile eski kiracıya kiraya verme zorunluluğu bakımından eski kiracıya kiraya verme

\footnotetext{
27 ZEVKLİLER / GÖKYAYLA, s. 356; İNCEOĞLU, C. 2, s. 534.

28 Aynı yönde AKYİĞİT, s. 214; AKGÜN AKAY, s. 93-s. 94, s. 115; AYDOĞDU / KAHVECİ, s. 667; AKYİĞİT, s. 214; İNCEOĞLU, C. 2, s. 402, s. 422, s. 535; ÖZDOĞAN / OYMAK, s. 582; ÖZTÜRK, s. 1568. Yargitay 7. Ceza Dairesi 02.05.1978 T. 1978/2066 K. 1978/2774 K.; karar için bkz. GÜLER (A.), s. 634. Aksi görüş için bkz. CERAN, s. 955.

29 İNCEOĞLU, C. 2, s. 535. Aynı doğrultuda bkz. ZEVKLILLER / GÖKYAYLA, s. 356; AKYİ̈̆İT, s. 214.

30 İNCEOĞLU, C. 2, s. 536.
} 
zorunluluğunun başlangıç tarihinin kiralananın tahliye tarihi olduğunu söylemek yanlış olmayacaktır ${ }^{31}$. Buna karşılık eski kiracının öncelikle kiralama hakkının kullandırtılmamasına dayalı eski kiracıya kiraya verme zorunluluğunun başlangıç tarihini, esaslı onarımın tamamlanıp kiralananın kiraya hazır hale getirildiği tarihi kabul etmek yerinde olacaktır ${ }^{32}$.

İhtar, mahkeme karar veya icra takip tarihi, eski kiracıya kiraya verme zorunluluğunun süresinin başlangıç tarihi olarak kabul edilebileceği söylenebilirse ${ }^{33}$ de eski kiracıya kiraya verme zorunluluğu süresinin kısalmasına neden olmaması için yukarda belirttiğim tarihin, eski kiracıya kiraya verme zorunluluğunun başlangıç tarihi olarak kabul edilmesi yerinde olacaktır.

Taraflar, süreyi kısaltmamak şartıyla kira sözleşmesiyle eski kiracıya kiraya verme zorunluluğunun süresinin başlangıç ve sona erme tarihini belirleyebilirler ${ }^{34}$. Kira sözleşmesinde bir hüküm bulunmaması halinde üç y1llık süre, TBK m.92/f.1 b.3 hükmüne göre hesaplanır. Buna göre kiralananın tahliye edildiği gün ayın kaçıncı günü ise, üç yıl sonraki aynı ayın bunu karşılayan gününde üç yıllık süre dolmuş olur. Son ayda bunu karşılayan gün yoksa süre, bu ayın son günü süre tamamlanmış sayılır.

31 İNCEOĞLU'na göre üç yıllık sürenin fiili tahliye tarihinden itibaren işlemeye başlayacağ 1 kabul edilmelidir; İNCEOĞLU, C. 2, s. 538. Aynı doğrultuda bkz. YAVUZ, s. 347; ÖZDOĞAN / OYMAK, s. 579; AKGÜN AKAY, s. 92; ÖZTÜRK, s. 1568; SARUHAN, s. 366. AKYİĞIT'e göre "kiracıya boşaltım için (kiraya veren veya mahkemece) bir süre verilmemişse; mahkeme kararının kesinleştiği tarihten başlatımı uygundur. Lakin boşaltım için kiractya bir süre verilmişse, süre bitmeden boşaltılmışsa, bu süre boşaltım tarihinden; ama süre bittiği halde boşaltılmadı̆̆ındaysa, tanınan sürenin bitiminden başlatmanın isabet taşıdĭ̆ d düşünülür.”; AKYİĞİT, s. 214.

32 Aynı görüş bkz. AKYİĞİT, s. 215. Diğer yandan kiraya verenin yeniden kiralama teklifini, en kısa sürede yapmasının dürüstlük kuralına uygun olacağı hakkında bkz. AKYİĞİT, s. 214. Aksi görüşte olan İNCEOĞLU'na göre “Kanaatimce inşa ve tadilat faaliyetlerinin bitmesinden sonra dürüstlük kuralına göre en kısa zamanda teklifin yapılması gerektiği yönündeki görüss isabetli değildir. Zira yukarıda da ifade edildiği üzere, kiraya veren taşınmazı kendisi kullanacak ise böyle bir öncelik hakkı mevcut değildir. Kiraya verenin taşınmazı öncelikle kendi kullanmak istemesi, sonra bundan vazgeçmesi olasıdır ve bu husus başlı başına kanuna ya da dürüstlük kuralına aykırı olmayacakttr. Bu nedenle teklifin derhal yapılması gerektiğinin kabul edilmesi mümkün değildir.”; bkz. İNCEOĞLU, C. 2, s. 539.

33 İNCEOĞLU, C. 2, s. 538.

34 AKYİĞİt, s. 213. Ancak hükmün nispi emredici özelliği nedeniyle sürelerin kısaltılması geçersiz olacaktır. Bkz. İNCEOĞLU, C. 2, s. 534, s. 539. 


\section{V- HAKLI SEBEBİN BULUNMAMASI}

Kiraya verenin eski kiracısına kiraya verme zorunluluğu, haklı sebebin ${ }^{35}$ bulunması halinde söz konusu olmaz. Haklı sebep kavramı, mücbir sebep kavramına göre daha geniştir ${ }^{36}$. Diğer bir anlatımla haklı sebep kavramı mücbir sebep kavramına oranla kiraya verenin eski kiracıya kiraya verme zorunluluğunu daraltan bir özelliğe sahiptir ${ }^{37}$. Kiralananın kamulaştırılması, doğa olayları sonucunda yok olması gibi kiraya verenden kaynaklanmayan ve kaçınılmaz olarak gerçekleşen olaylar, eski kiracıya kiraya verme zorunluluğu bakımından mücbir sebep teşkil eder ${ }^{38}$.

Bunların yanında haklı sebebin varlığı, eski kiracıya kiraya verme zorunluluğuna yol açan kira sözleşmesinin sona erdirilmesi nedenleri bakımından ayrı ayrı değerlendirilmelidir. Gereksinim nedeniyle kiralananın boşaltılması sonrasında kiraya verenin ölüm, hastalık, tayininin çıkması gibi beklenmeyen bir gelişme sonucunda kiralananı kullanamaması halinde haklı sebebin varlığı kabul edilebilir ${ }^{39}$. Aynı şekilde kiraya verenin hastalanması

35 Haklı sebep, mücbir sebebi de kapsayan beklenmedik olaylardır. Beklenmedik olayı, doğal, sosyal veya hukukî bir olay olabileceği gibi, insana bağlı beşerî bir olay, bir davranış da olabilir. Beklenmedik olayların başında savaş, iç savaş, darbe, ayaklanma, deprem, ağır firtına, sel, yangın, yıldırım düşmesi, don, yer çökmesi, genel grev, ithalat ve ihracat yasaklamaları, sınırların kapatılması, düşman mallarına el konması gelir. Haklı sebep kavramı hakkında detaylı bilgi için bkz. EREN, (2018), s. 518, s. 583-586; EREN, (2017), s. 52. AKYİĞİT'e göre haklı sebep, gereksinim yüzünden boşalttırılan kiralananın henüz üç yıl dolmadan başkasına kiraya verilmesini haklı, saygıya değer gösteren "objektif olgular" olarak anılabilir ya da boşalttırılan kiralananın başkasına kiraya verilmeden üç yıl beklenilmesini çekilmez, artık katlanılmaz kılan durumlar olarak tanımlanabilir. Bu bir doğal afet veya genel ya da bireysel/sektörel bir kriz veyahut icra-iflas tehdidi, hatta eski kiracının orayı kiralamaktan vazgeçmesi olabilir; bkz. AKYİ̈̆İT, s. 211.

36 ACAR (YAVUZ / ÖZEN / ACAR), (2016), s. 347; İNCEOĞLU, C. 2, s. 536; AKYİĞİT, s. 211. Kiraya verenin kendisinden kaynaklanan sebeplerin haklı sebep oluşturmayacağı, bu hallerin kiraya verenin sağlığı gibi- kiralananın eski kiracıya kiralanmasını engellemeyeceği yönündeki görüş için bkz. AYDOĞDU / KAHVECİ, s. 665.

37 Haklı sebep kiracıdan kaynaklanan hallerle sınırlandırılmalıdır; bkz. AYDOĞDU / KAHVECİ, s. 665.

38 AYDOĞDU / KAHVECİ, s. 666.

39 AYDEMIR, s. 208; AKGÜN AKAY, s. 92. "Örneğin hastalanmış ve mesleği ya da sanatını bırakmış yahut da başka bir kente göçmüşse zorunlu bir sebebin varlığı kabul edilebilir.”; bkz. ZEVKLİLER / GÖKYAYLA, s. 355. Gereksinim nedeniyle kiralananı tahliye ettiren kiraya verenin, üç yıllık süre içerisinde, eski kiracıya kiralama teklifinin eski kiracı tarafından kabul edilmemesi, eski kiracı başka taşınmaza taşınmış olacağından ve tekrar eski kiralanana geçmek istemeyeceğinden, üçüncü kişi ile kira sözleşmesi yapılmasını haklı kılmaz; bkz. İNCEOĞLU, C. 2, s. 403. Eski kiracının kabul etmemesi halinde, bunun haklı sebep sayılacağına ve kiraya verenin kiralananı başkasına kiraya verebileceğine dair aksi görüş 
sebebiyle söz konusu konutta oturamaz hale gelmesi veya mesleği ya da sanatını bırakması haklı bir sebep olarak benimsenebilir ${ }^{40}$. Buna karşın bu sebepler, esaslı onarım bakımından haklı sebep olarak kabul edilmemelidir.

Yeniden inşa ve imar amacıyla esaslı onarım nedeniyle kiralananın boşaltılması halinde haklı sebep, daha çok eski kiracıya ilişkin ortaya çıkar. Burada eski kiracının tayininin çıkması, hastalanması, meslek veya sanatını bırakması gibi nedenlerle kiralananı kiralama olanağının kalmaması haklı sebep olarak değerlendirilebilir ${ }^{41}$. Kiralananın esaslı onarım sonrasında işyerine dönüşmesi ve eski kiracının kiralananı yeni haliyle konut olarak kullanması mümkün değilse, haklı sebebin varlığı kabul edilmelidir ${ }^{42}$. Ölüm olay1 kira sözleşmesinin kendiliğinden sona ermesine yol açan bir hal olarak düzenlenmediğinden ve esas olan bu durumda kira sözleşmesinin mirasçılarla devam etmesi olduğundan, eski kiracının ölmesi haklı sebep olarak kabul edilmemelidir ${ }^{43}$. Ayrıca eski kiracının başka yerde oturmaya başlaması, eski kiracıya kiralama olanağının kalmadığ 1 şeklinde yorumlanmamalıdır ${ }^{44}$.

Haklı sebebin kiralananın boşaltılmasından sonra eski kiracı dışında bir üçüncü kişiye kiralanırken bulunması yeterlidir ${ }^{45}$.

Yasa hükmünde, kira sözleşmesinin gereksinim nedeniyle sona erdirilmesi ile kiralananın esaslı onarım amacıyla boşaltılması sonrasında eski hali ile kiraya verilmesi bakımından haklı sebebe yer verilmiş olup, eski kiracının öncelikle kiralama hakkının kullandırtılmaması bakımından haklı sebebe yer verilmemiştir (TBK m. 355/I, II). Bununla birlikte kiracının öncelikle kiralama hakkının kullandırtılmamasının haklı sebebe dayalı olması halinde, eski kiracıya kiraya verme zorunluluğuna neden olan kira sözleşmesinin sona erdirilmesi diğer nedenlerinde olduğu gibi burada da eski kiracıya kiraya verme zorunluluğu söz konusu olmamalıdır.

için bkz. ÖZDOĞAN / OYMAK, s. 580.

40 ZEVKLILLER / GÖKYAYLA, s. 355.

${ }_{41}$ Türk Borçlar Kanunu'nun 355. maddesi anlamında haklı sebep kiraya verenin sona erme sırasında mevcut olan ihtiyacının sonradan ortadan kalkması şeklinde de ortaya çıkabilecektir; bkz. İNCEOĞLU, C. 2, s. 536.

42 Konutun işyerine dönüşmesi haklı sebep olmasına karşın kiracının başka yerde oturmaya başlaması haklı sebep teşkil etmez; bkz. İNCEOĞLU, C. 2, s. 420.

43 İNCEOĞLU, C. 2, s. 401-402. Öncelikle kiralama hakkının ölen kiracının mirasçılarına teklif edilmesi gerektiği yönünde bkz. AKYİĞİT, s. 213; İNCEOĞLU, C. 2, s. 537.

44 İNCEOĞLU, C. 2, s. 537.

45 SARUHAN, s. 364. 


\section{VI- KIIRAYA VERME ZORUNLULUĞUNA NEDEN OLMAYAN EYLEMLER}

Kiraya verenin kiralananı eski kiracısı dışındaki kişilere kiraya vermemesi anlamına gelen kiraya verme zorunluluğunun, kiraya verilmesi dışındaki eylemleri kapsayıp kapsamadığının değerlendirilmesi gereklidir. Söz gelimi kiralanan üzerinde intifa hakkı tesis edilmesi, eski kiracıya kiraya verme zorunluluğu dişında olduğu söylenebilir. Aynı şekilde gereksinim nedeniyle boşaltılması sağlanan kiralananın üçüncü bir kişiye satılması veya ücretsiz kullandırtılması eyleminin eski kiracıya kiraya verme zorunluluğunu dışında olduğu söylenebilitr ${ }^{46}$.

Kiralama dışındaki eylemlerin eski kiracıya kiraya verme zorunluluğu dışında olup olmadığının belirlenmesinde kiraya verenin kira bedeli benzeri bir gelir elde edip etmediği ölçüt olarak kabul edilebilir. Söz gelimi üçüncü kişiye intifa veya oturma hakkı tanınması halinde kira benzeri bir gelirin elde edileceği söylenebilir. Bu nedenle bu tip eylemlerin eski kiracıya kiraya verme zorunluluğu kapsamında olduğu söylenebilir. Buna karşın kiralananın üçüncü kişiye ücretsiz kullandırtılması veya kiralananın satılması halinde kira geliri benzeri bir gelirin elde edilmesi söz konusu olmadığından bu tip eylemlerin eski kiracıya kiraya verme zorunluluğu dışında olduğu söylenebilir ${ }^{47}$. Ancak kiralananın üçüncü kişiye ücretsiz kullandırtılmasının eski kiracıya kiraya verme zorunluluğu süresince olması gereklidir. Aynı şekilde kiralananın üçüncü kişiye ücretsiz kullandırtılması, kiraya verme zorunluluğu süresinin son bulmasından önce sona ermesi halinde kalan sürede eski kiracıya kiraya verme zorunluluğunun bulunduğu kabul edilmelidir.

Diğer yandan gereksinim nedeniyle kira sözleşmesinin sona erdirilmesinde kiralananın eski kiracı dışında başkasına kiraya verilmesinden anlaşılması gereken, gereksinim iddiası kabul edilenler dışındaki kişilere kiraya verilmesi olduğu açıktır ${ }^{48}$.

\section{VII-SONUÇ}

Sözleşmenin karşı tarafını seçme özgürlüğüne kanunla getirilen bir sınırlama olarak kiraya verenin eski kiracısına kiraya verme zorunluluğu, konut

\footnotetext{
46 AKYİĞİT, s. 217; İNCEOĞLU, C. 2, s. 536; SARUHAN, s. 365.

47 İNCEOĞLU, C. 2, s. 536. Yeniden inşa faaliyeti sonunda, kiralanan bir üçüncü kişiye satılmış ise, kiraya veren sıfatına haiz olmayan yeni malikin eski kiracıya yeniden kiralama teklifinde bulunmasina gerek yoktur; bkz. SARUHAN, s. 371.

48 Aynı yönde AYDOĞDU / KAHVECİ, s. 664; AKGÜN AKAY, s. 91.
} 
ve çatılı işyeri kira sözleşmesinin kiraya verenin veya yeni malikin kiralanana gereksinim nedeniyle kira sözleşmesini sona erdirmesi ile kiralananın esaslı onarımı nedeniyle kiraya veren tarafından kira sözleşmesinin sona erdirilmesi hallerinde söz konusudur. Bunlara ilaveten eski kiracının, yeniden inşa ve imarı gerçekleştirilen kiralananı yeni durumu ve yeni kira bedeli ile kiralama konusundaki öncelik hakkı sonlandırılmadıkça, kiraya verenin eski kiracısına kiraya verme zorunluluğu bulunmaktadır.

Kiraya veren dişında, malik veya intifa hakkı sahibinin kiralanana olan gereksinimi nedeniyle kira sözleşmesini sona erdirmesi halinde de eski kiracıya kiraya verme zorunluluğunun bulunduğu kabul edilmelidir. Yine eski kiraya verenle kiracı arasındaki kira sözleşmesine halef olan kiralananı sonradan edinen malikin, kira sözleşmesini gereksinim nedeniyle sona erdirmesi halinde yeni malik için de eski kiracıya kiraya verme zorunluluğunun geçerli olduğu kabul edilmelidir. Ayrıca kiralananı sonradan edinen malikin kira sözleşmesine halef olarak değil, kiralananı sonradan edinen malik olarak gereksinim nedeniyle kira sözleşmesini sona erdirmesi halinde de eski kiracıya kiraya verme zorunluluğunun geçerli olduğu kabul edilmelidir.

Eski kiracıya kiraya verme zorunluluğunun geçerli olabilmesi için kira sözleşmesinin kiraya veren tarafından sona erdirilmesi yanında kiracının kiralananı tahliyeye zorlanması gereklidir. Bunun için kiracının mutlaka dava edilerek tahliye edilmesi aranmamalı, tarafların anlaşmaları veya ihtar üzerine kiralananın boşaltılması halinde de eski kiracıya kiraya verme zorunluluğunun geçerli olduğu benimsenmelidir.

Eski kiracıya kiraya verme zorunluluğunun başlangıç tarihi, eski kiracıya kiraya verme zorunluluğuna neden olan kira sözleşmesinin sona erdirilmesi nedenleri gözetilerek ayrı ayrı değerlendirilmelidir. Gereksinim nedenine dayalı veya esaslı onarım sonrasında kiralananın eski hali ile eski kiracıya kiraya verme zorunluluğu bakımından eski kiracıya kiraya verme zorunluluğunun başlangıç tarihinin kiralananın tahliye tarihi, eski kiracının öncelikle kiralama hakkının kullandırtılmamasına dayalı eski kiracıya kiraya verme zorunluluğunun başlangıç tarihinin ise esaslı onarımın tamamlanıp kiralananın kiraya hazır hale getirildiği tarihi kabul etmek yerinde olacaktır.

Eski kiracıya kiraya verme zorunluluğunu ortadan kaldıran haklı sebep, eski kiracıya kiraya verme zorunluluğuna yol açan kira sözleşmesinin sona erdirilmesi nedenleri bakımından ayrı ayrı değerlendirilmelidir. Ayrıca öncelikle kiralama hakkına ilişkin Yasa hükmünde haklı sebebe yer verilmemiş 
olmakla birlikte öncelikle kiralama hakkının kullandırtılmamasının haklı sebebe dayalı olması halinde de eski kiracıya kiraya verme zorunluluğunun bulunmadığı kabul edilmelidir.

Kiraya verenin kiraya verme dışındaki eylemlerinin eski kiracıya kiraya verme zorunluluğuna neden olmayabileceği düşünülebilirse de kiralama dışındaki eylemlerin eski kiracıya kiraya verme zorunluluğu dışında olup olmadığının belirlenmesinde kiraya verenin kira bedeli benzeri bir gelir elde edip etmediği ölçüt olarak dikkate alınmalıdır.

\section{KAYNAKÇA}

ACAR, Faruk: Kira Hukuku Şerhi, 4. Bası, Yayınevi, İstanbul, 2017. “ACAR, (2017)".

ACAR, Faruk (YAVUZ / ÖZEN / ACAR): Borçlar Hukuku Dersleri Özel Hükümler, 14. Bas1, Beta Yayınevi, İstanbul, 2016. " $A C A R$, (2016)".

AKGÜN AKAY, Merve: Konut ve Çatılı İşyeri Kira Sözleşmelerine Özgü Sona Erme Nedenleri, Seçkin Yayıncılık, Ankara, 2017.

AKINCI, Şahin: Borçlar Hukuku Bilgisi Genel hükümler, 10. Bası, Sayram Yayınlar1, Konya, 2017. “AKINCI, (2017)".

AKINCI, Şahin: "İşyeri Kiralarında Kiracının Korunması Açısından Borçlar Kanunu Tasarısının Bazı Hükümlerinin Değerlendirilmesi”, AÜHFD, Y. 2008, C. 57, Sa. 3, s. 33-50. "AKINCI, (2008)".

AKINTÜRK, Turgut/ATEŞ KARAMAN, Derya: Borçlar Hukuku, Genel Hükümler, Özel Borç İlişkileri, 25. Basıdan Tıpkı Basım 26. Bası, Beta Yayınevi, İstanbul, 2017.

AKYİĞIT, Ercan: 6098 Sayılı Türk Borçlar Kanunu'nda Kira Sözleşmesi, Ankara, 2012.

ANTALYA, Gökhan O.: Borçlar Hukuku Genel Hükümler, C. 1, 3. Bası, Legal Yayınevi, İstanbul, 2018.

ARAL, Fahrettin / AYRANCI, Hasan: Borçlar Hukuku Özel Borç İlişkileri, 11. Bası, Yetkin Yayınevi, Ankara, 2015. 
ARPACI, Abdülkadir (HATEMİ, Hüseyin / SEROZAN, Rona / ARPACI, Abdülkadir): Borçlar Hukuku Özel Bölüm, Filiz Kitapevi, İstanbul, 1992.

AYAN, Mehmet: Borçlar Hukuku, 10. Bası, Mimoza Yayınevi, Konya, 2015.

AYAN, Nurşen: "Kira Konusu Taşınmazın İhtiyaç Nedeniyle Tahliye Ettirilmesi”, Selçuk Üniversitesi Hukuk Fakültesi, Y. 2007, C. 15, Sa. 2, s. 11-24.

AYANOĞLU MORALI, Ahu: İstanbul Şerhi Türk Borçlar Kanunu / TBK m.347, C. 2, Vedat kitapçılık, İstanbul, 2018.

AYBAY, Aydın: Borçlar Hukuk Dersleri Genel Bölüm, 14. Bası, Filiz Kitapevi, İstanbul, 2016.

AYDEMİ, Efrail: Kira Hukuku, 4. Bası, Seçkin Yayıncılık, Ankara, 2016.

AYDIN, Gülşah Sinem: Kira Sözleșmesinin Genel Hükümlere Göre Sona Ermesi, On İki Levha Yayınları, İstanbul, 2013.

AYDOĞDU, Murat / KAHVECİ, Nalan: Türk Borçlar Hukuku Özel Borç İlişkiler, 3. Bası, Adalet Yayınevi, Ankara, 2017.

AYSAL, Mustafa: "Konut ve Çatılı İşyeri Kiralarında Sözleşmenin Sona Ermesi”, Bahçeşehir Üniversitesi Hukuk Fakültesi Kazancı Hakemli Hukuk Dergisi, Y. 2103, C. 9, Sa. 103-104, s. 183-191.

BAŞPINAR, Veysel: Borç Sözleşmelerinin Kısmi Butlanı, Batider Yayınları, Ankara, 1998.

BATUR, İsmail Cenk: "Konut Gereksinimine Dayalı Tahliye Davalarında "Samimi ve Gerçek İhtiyaç" Kavramı", İBD, Y. 2017, C. 91, Sa. 6, s. 216-220.

BİLGİİ, Fatih/DEMİRKAPI, Ertan: Borçlar Hukuku Genel Hükümler, 8. Bası, Dora Yayınları, Bursa, 2016.

BİRINCİ UZUN, Tuba: "Belirli Süreli Konut ve Çatılı İşyeri Kira Sözleşmelerinin Kiraya Veren Tarafından Bildirim Yoluyla Sona Erdirilmesinde On Y1llı Uzama Süresi (TBK m. 347 f.1)", İnönü Üniversitesi Hukuk Fakültesi Dergisi, Y. 2017, C. 8, Sa. 2, s. 137-158. BURCUOĞLU, Haluk: 6570 Sayılı yasaya Göre Kiracını Tahliye Edilmesi, Filiz Kitapevi, İstanbul 1993. "BURCUOĞLU, (1993)”" 
BURCUOĞLU, Haluk: “Borçlar Kanunu Tasarısı'nın Haksız Eylem Sorumluluğu ve Kira İle İlgili Düzenlemesiyle Getirilen Yenilikler”, Prof. Dr. Turgut Akıntürk'e Armağan (Editörler: Ateş, Derya/Bulur, Alper), Beta Yayınevi, İstanbul, 2008, s. 18-46. "BURCUOĞLU, (2008)”,

CERAN, Mithat: Kira Sözleşmeleri Tahliye ve Tespit Davaları, 2. Bası, Yetkin Yayınevi, Ankara, 2015.

DOĞAN, Murat: Konut ve Çatılı İşyeri Kira Sözleşmelerini Sona Ermesi, Ankara, 2011. "DOĞAN, Konut ve Çatılı".

DOĞAN, Murat: “6098 Sayılı TBK'na göre Konut ve Çatılı İşyeri Kiralarına İlişkin Hükümlerin Değerlendirilmesi”, Marmara Üniversitesi Hukuk Fakültesi Hukuk Araştırmaları Dergisi: Prof. Dr. Cevdet Yavuz'a Armağan, Özel Hukuk Sempozyumu Özel Sayısı, 6098 Sayılı Türk Borçlar Kanunu Hükümlerinin Değerlendirilmesi Sempozyumu, 3-4 Haziran 2011, Sempozyum No:3, Y. 2011, s. 501-519. "DOĞAN, 6098 Sayılı".

ERDOĞAN, Hasan: Tahliye, Kira Tespit, Kira Alacağı, Tazminat Davaları, 2. Bas1, Adalet Yayınevi, Ankara, 2010.

EREN, Fikret: Borçlar Hukuku Genel Hükümler, 23. Bası, Yetkin Yayınevi, Ankara, 2018. "EREN, (2018)".

EREN, Fikret: Borçlar Hukuku Özel Hükümler, 5. Bası, Yetkin Yayınevi, Ankara, 2017. "EREN, (2017)".

ERZURUMLUOĞLU, Erzan: Sözleşmeler Hukuk (Özel Borç İlişkileri), 7. Bası, Yetkin Yayınevi, Ankara, 2017.

EKINCİ, Hüseyin: "Tahliye Edilen Taşınmazın Eski Kiracıya Yeniden Kiralanması Zorunluluğu”, Adalet Dergisi, Y. 2005, Sa. 23, s. 88-116.

GÖKYAYLA, Emre: İstanbul Şerhi Türk Borçlar Kanunu / TBK M.339, C. 2, Vedat kitapçılık, İstanbul, 2018. "GÖKYAYLA, (2018)"

GÖKYAYLA, Emre: “Konut ve Çatılı İşyeri Kiralarına İlişkin Hükümlerin Uygulama Alanı (TBK m. 389)", Yaşar Üniversitesi Elektronik Dergisi: Prof. Dr. Aydın Zevkliler'e Armağan, Y. 2013, C. 8, Özel Say1, Cilt 2, s. 1203-1252. "GÖKYAYLA, (2013)”

GÜLER, Alev: “6570 Sayılı Kira Kanunu’nun 15-16 Maddelerinin Uygulanmasında Ortaya Çıkan Sorunlar”, ABD, Y. 1978, Sa. 4, s. 632635. 
GÜLER, Zeynep: “Konut ve Çatılı İşyeri Kiralarında Sözleşmenin Kiraya Verenden Kaynaklanan Sebeplerle Dava Yoluyla Sona Ermesi”, İstanbul Kültür Üniversitesi Hukuk Fakültesi Dergisi, Y. 2016, C. 15, Sa. 2, s. 713-748.

GÜMÜŞ, Mustafa Alper: Kira Sözleşmesi, Vedat Kitapçılık, İstanbul, 2012.

GÜNAY, Erhan: Konut ve Çatılı İşyeri Kiralarında Kira Tespiti ve Kira Sözleşmesinin Sona Erdirilmesi, Seçkin Yayıncılık, Ankara, 2017.

GÜRZUMAR, Osman Beraat: Zorunlu Unsur Doktrinine Dayalı Sözleşme Yapma Yükümlülüğü, Seçkin Yayınevi, Ankara, 2006.

HATEMİ / GÖKYAYLA, Borçlar Hukuku Genel Bölüm, 4. Bası, Vedat Kitapçılık, İstanbul, 2017

İKIZLER, Metin: "Kiralananın Satılması Durumunda Alıcının Satıcıya Karşı Hakları", Gazi Üniversitesi Hukuk Fakültesi Dergisi, Y. 2016, C. 20, Sa. 2, s. 25-59.

İNAN, Ali Naim/YÜCEL, Özge: İnan Borçlar Hukuku Genel Hükümler, 4. Bası, Seçkin Yayıncılık, Ankara, 2014.

İNCEOĞLU, M. Murat: Kira Hukuku, C. 1, C. 2, Oniki Levha Yayınları, İstanbul, 2014.

IPEK, Eyüp: “6098 Sayılı Türk Borçlar Kanunu İle Konut Ve Çatılı İşyeri Kiralarında Tahliye Sebeplerine İlişkin Getirilen Yenilikler”, TBB Dergisi, Y. 2012, Sa. 102, s. 59-92.

KAHRAMAN, Zafer: İstanbul Şerhi Türk Borçlar Kanunu / TBK m.299, C. 2, Vedat kitapçıl1k, İstanbul, 2018. "KAHRAMAN, M. 299”

KAHRAMAN, Zafer: İstanbul Şerhi Türk Borçlar Kanunu / TBK m.300, C. 2, Vedat kitapçılık, İstanbul, 2018. "KAHRAMAN, M. 300”

KALENDER, Ahmet: "Konut ve Çatılı İşyeri Kiralarında Sözleşmenin Sona Ermesi”, Terazi Hukuk Dergisi, Y. 2017, C. 12, Sa. 136, s. 27-35.

KILIÇOĞLU, Ahmet M.: Borçlar Hukuku Genel Hükümler, Genişletilmiş 22. Bas1, Turhan Kitapevi, Ankara, 2018.

KILIÇOĞLU, Mustafa: Kira Hukuku'ndan Doğan Tahliye, Tespit, Uyarlama, Tazminat ve Alacak Davaları, 3. Bası, Bilge Yayınevi, Ankara, 2015. 
KIRMIZI, Mustafa: Konut ve Çatılı İşyeri Kiraları, Bilge Yayınevi, Ankara, 2013.

KOÇ, Nevzat: “6098 Sayılı Türk Borçlar Kanunu’nda Kira Sözleşmesine İlişkin Olarak Yapılan Yeni Düzenlemelerin Genel Değerlendirmesi”, İstanbul Medipol ÜHFD, Y. 2014, C. 1, Sa. 1, s. 7-35.

KOÇAK DİKER, Duygu: Konut ve Çatılı İşyeri Kiralarında Kiracının Ödeme Dışındaki Yan Borçlarına Aykırılığı ve Sözleşmenin Kiraya Veren Tarafından Sona Erdirilmesi, Oniki Levha Yayınları, İstanbul, 2018.

KOCAYUSUFPAŞAOĞLU, Necip (KOCAYUSUFPAŞAOĞLU / HATEMI / SEROZAN / ARPACI): Borçlar Hukuku Genel Bölüm, C. 1, 2010 Tarihli 5. Basıdan Tipk1 6. Bas1, Filiz Kitapevi, İstanbul, 2014.

KÖSTEKÇİ, Yaşar: 10 Yıl Uzama Süresi Sonu Kiracının Tahliyesi Tahliyeden Korunma Önlemleri, Vedat Kitapçılık, İstanbul, 2014.

KURŞAT, Pelin: Konut ve Çatılı İşyeri Kira Sözleşmesinin Bildirim Yoluyla Sona Erdirilmesi, Filiz Kitapevi, İstanbul, 2017.

NOMER, Haluk N.: Borçlar Hukuku Genel Hükümler, Genişletilmiş 16. Bas1, İstanbul, 2018.

OĞUZMAN, Kemal / ÖZ, M. Turgut: Borçlar Hukuku, Genel Hükümler, C. 1, 16. Bası, Vedat Kitapçılık, İstanbul, 2018.

ÖKTEM ÇEVIK, Seda: İstanbul Şerhi Türk Borçlar Kanunu / TBK m.310, C. 2, Vedat kitapçılık, İstanbul, 2018.

ÖZDOĞAN, Mustafa / OYMAK, Tuba: 6098 Sayılı Borçlar Kanunu'nda Kira, Bilge Yayınevi, Ankara, 2013.

ÖZTÜRK, Mehmet: "Konut ve Çatılı İşyeri Kira Sözleşmelerinin Sona Erme Halleri”, DEÜHFD: Prof. Dr. Şeref ERTAŞ’a Armağan Özel Sayısı, Y. 2017, C. 19, s. 1549-1595.

REİSOĞLU, Safa: Borçlar Hukuku Genel Hükümler, 25. Bası, Beta Yayınevi, İstanbul, 2014.

RUHI, Ahmet Cemal: Kira Hukuku, C. 1, Seçkin Yayınevi, Ankara, 2011.

RUHI, Canan / RUHI, Ahmet Cemal: Türk Borçlar Kanunu'na Göre Kira Hukuku, Seçkin Yayıncılık, Ankara, 2016. 
SANLI, Kerem Cem: "Kiraya Verenin On Y1llık Uzama Süresi Sonunda Bildirim İle Kira Sözleşmesini Sona Erdirmesi: Hukuk ve Ekonomi Perspektifinden Bir İnceleme", Legal Hukuk Dergisi, Y. 2015, C. 13, Sa. 151 , s. 103-148.

SARUHAN, Utku: "Yeniden Kiralama Yasağı (TBK m.355)", TAAD, Y. 2019, C. 10, Sa. 37, s. 353-383.

SEROZAN, Rona: TBK M.1, TBK İstanbul Şerhi, C. 1, Vedat Kitapçılık, İstanbul, 2018.

ŞENER, Oruç Hami: İşyeri İhtiyacı Nedeniyle Tahliye Davaları ve Ortaklıklar Hukukuyla Bağlantısı, Seçkin Yayıncılık, Ankara, 2010.

TEKINAY / AKMAN / BURCUOĞLU / ALTOP, Tekinay Borçlar Hukuku, Genel Hükümler, 7. Bası, Filiz Kitapevi, İstanbul, 1993.

TERCIER, Pierre / PICHONNAZ, Pascal / DEVELIOĞLU, H. Murat: Borçlar Hukuku Genel Hükümler, On İki Levha Yayıncılık, İstanbul, 2016.

TOSUN, Yalçın: "Konut ve Çatılı İssyeri Kiralarında Kiraya Verenin Gereksinimi”, Bahçeşehir Üniversitesi Hukuk Fakültesi Dergisi, Y. 2016, C. 11, Sa. 137-138, s. 31-53.

TUNABOYLU, Müslim: Kira Sözleşmesinde Fesih ve Tahliye Davaları, Yetkin Yayınevi, Ankara, 2013.

UYGUR, Turgut: Borçlar Kanunu, Özel Borç İlişkileri, C. 6, Seçkin Yayınevi, Ankara, 2003.

ÜNAL, Canan: "Yargıtay Kararları Işı̆̆ında Borçlar Kanunu ve Gayrimenkul Kiraları Hakkında Kanuna Göre Kira Sözleşmesinin Sona Erme Nedenleri”, İBD, Y. 2010, C. 84, Sa. 3, s. 1525-1543.

YAVUZ, Nihat: Kira Hukuku, 6. Bası, Adalet Yayınevi, Ankara, 2018.

ZEVKLILER, Aydın / ERTAȘ, Șeref / HAVUTÇU, Ayșe / AYDOĞDU, Murat / CUMALIOĞLU, Emre: Borçlar Hukuku Genel Hükümler ve Özel Borç İlişkileri, 2. Bası, Barış Yayınları, İzmir, 2013.

ZEVKLİLER, Aydın / GÖKYAYLA, K. Emre: Borçlar Hukuku Özel Borç İlişkileri, 17. Bası, Turhan Kitapevi, Ankara, 2017. 
